\author{
Jan KUSIŃSKI ${ }^{1}$ \\ Sławomir KĄC ${ }^{2}$ \\ Kazimierz KOWALSKI ${ }^{3}$ \\ Paolo MATTEAZZI ${ }^{4}$ \\ Sergi DOSTA ${ }^{5}$ \\ Emmanuel GEORGIU ${ }^{6}$
}

\title{
NATRYSKIWANE ZIMNYM GAZEM POWŁOKI ODPORNE NA ŚCIERANIE
}

\begin{abstract}
Naukowym i technologicznym celem badań było wytworzenie nanostrukturalnych powłok $\mathrm{FeCuAl}-\mathrm{Al}_{2} \mathrm{O}_{3}$, WC-CoAl, Ni-Sn, TiC/Ti o grubości od 45 do $500 \mu \mathrm{m}$. Nanoproszki charakteryzujące się strukturą krystaliczną i równomiernym rozmieszczeniem składników otrzymywano, stosując wysokoenergetyczną syntezę mechaniczną. Proszek o strukturze nanokrystalicznej był nanoszony na podłoże bez istotnych zmian jego struktury i właściwości, $\mathrm{z}$ wykorzystaniem nowej technologii (natryskiwania zimnym gazem - CGS), pozwalającej uzyskiwać powłoki o dużej gęstości. Mikrostrukturę oraz skład chemiczny nanoproszków i nanoszonych powłok analizowano, wykorzystując mikroskopię świetlną, TEM, STEM, SEM/EDS, XPS oraz XRD. Ponadto mierzono współczynnik tarcia oraz odporność na ścieranie powłok. Przeprowadzone badania wykazały, że mikrostruktura powłok odpowiada strukturze nanoszonych proszków. Dzięki nanostrukturalnej budowie powłok, właściwej proporcji faz twardych i miękkich, natryskiwane zimnym gazem powłoki wykazują lepsze właściwości trybologiczne w porównaniu z materiałami standardowo stosowanymi w przemyśle i bioinżynierii.
\end{abstract}

Słowa kluczowe: mechaniczna synteza, powłoki metal/ceramika, mikrostruktura, twardość, testy tribologiczne

\section{Wprowadzenie}

Charakterystyka materiału, jego potencjalne zastosowanie oraz kontrola i przewidywanie czasu jego eksploatacji wymagają zrozumienia oddziaływania

1 Autor do korespondencji/corresponding author: Jan Kusiński, AGH Kraków, al. Mickiewicza 30, 30-059 Kraków, e-mail: kusinski@agh.edu.pl

2 Sławomir Kąc, AGH Kraków, e-mail: Slawomir.Kac@agh.edu.pl

${ }^{3}$ Kazimierz Kowalski, AGH Kraków, e-mail: kkowalsk@agh.edu.pl

${ }^{4}$ Paolo Matteazzi, MBN Nanomaterialia, Treviso, Italy, e-mail: matteazzi@ mbn.it

${ }^{5}$ Sergi Dosta, University of Barcelona, Spain, e-mail: sdosta@ub.edu

${ }^{6}$ Emmanuel Georgiou, Catholic University of Leuven, Belgium, e-mail: Emmnuel.Georgiou@ mtm.kuleuven.be 
pomiędzy powierzchnią materiału i środowiskiem, które na niego oddziałuje. W prawie wszystkich technologiach wytwarzania wyrobów ich warstwy wierzchnie i naniesione powłoki odgrywają szczególną rolę $[1,2]$. Celem wytwarzania powłok na powierzchniach elementów maszyn i urządzeń jest ich ochrona przed korozją, zużyciem ściernym i erozyjnym, a tym samym ochrona przed chemicznym, mechanicznym i fizycznym oddziaływaniem środowiska. Natryskiwanie cieplne należy do najbardziej popularnych procesów uszlachetniania warstwy powierzchniowej materiałów spośród wielu różnorodnych procesów, takich jak: techniki zanurzeniowe, techniki napawania łukowego, plazmowego i laserowego, procesy PVD i CVD i inne [3]. Wśród technologii natryskiwania cieplnego należy wyróżnić: tradycyjne natryskiwanie płomieniowe, naddźwiękowe natryskiwanie płomieniowe (HVOF i HVAF), natryskiwanie plazmowe i łukowo-plazmowe oraz natryskiwanie detonacyjne.

Od ponad dwóch dekad coraz częściej jest stosowana nowa technologia natryskiwanie zimnym gazem (Cold Gas Spraying - CGS). Technologia ta została zastosowana do wytwarzania wysokiej jakości powłok zbudowanych z metali, stopów i kompozytów [3, 4]. Z uwagi na to, że strumień cząstek proszku o dużej prędkości jest wytwarzany przez zimny $\left(\mathrm{T}<800^{\circ} \mathrm{C}\right)$, wstępnie sprężony, a następnie rozprężony w dyszy de Lavala gaz, proces jest ,niskotemperaturowy”, prowadzony w stanie stałym. Pozwala to na wytwarzanie powłok charakteryzujących się szczególnymi właściwościami [5]. Dotychczasowe badania wskazują, że technologia CGS jest idealnym procesem wytwarzania powłok zbudowanych z materiałów „wrażliwych" na działanie wysokiej temperatury, do których można zaliczyć nanomateriały i materiały amorficzne, jak również materiały o dużym powinowactwie do tlenu, jak aluminium, miedź, tytan, oraz materiały, w których zachodzą przemiany fazowe, a także kompozyty typu osnowa metaliczna-węglik. W praktyce, w czasie osadzania powłok techniką CGS cząsteczki proszku uzyskują prędkość naddźwiękową od 500 do $900 \mathrm{~m} / \mathrm{s}$ (możliwe jest uzyskiwanie prędkości do $1200 \mathrm{~m} / \mathrm{s}$ ). Rozpędzone do takiej prędkości cząstki proszku w momencie uderzenia w powierzchnię podłoża ulegają odkształceniu plastycznemu, w wyniku czego spłaszczają się (tworząc tzw. splaty [6]) i tworzą powłokę. Odkształcenie plastyczne cząstek i podłoża ma miejsce wówczas, kiedy cząstki proszku osiągną prędkość większą od tzw. prędkości krytycznej. Tworzenie powłoki przez połączenia cząstek dolatujących z dużą prędkością następuje w wyniku tarcia na granicach cząstka/podłoże oraz cząstka/cząstka [7, 8].

Głównymi zaletami powłok nanoszonych techniką CGS są: występowanie w nich głównie naprężeń ściskających, struktura „warstwowa”, prawie 100\% gęstość, brak obecności tlenków, wtrąceń niemetalicznych i innych defektów. Na podstawie analizy bogatej literatury można wnioskować, że $\mathrm{w}$ porównaniu $\mathrm{z}$ innymi technologiami natryskiwania cieplnego technologia CGS ma wiele zalet [9-12]. Z uwagi na to, że w procesie CGS jest wykorzystywana wysoka energia kinetyczna cząstek o niskiej temperaturze, rozrost ziarna jest ograniczony. Dzięki 
temu możliwe jest otrzymywanie powłok z proszków o strukturze nanometrycznej.

Z uwagi na szczególne właściwości fizyczne i mechaniczne znacznie przekraczające właściwości materiałów krystalicznych i mikrokrystalicznych, materiały nanostrukturalne i nanopowłoki stanowią od wielu lat przedmiot wszechstronnych badań $[13,14]$. Na przestrzeni minionych lat wielokrotnie wykazano, że zastosowanie materiałów nanostrukturalnych do wytwarzania wysokojakościowych powłok zapewnia im dużą odporność na ścieranie, niski współczynnik tarcia (również w wysokich temperaturach) i odporność na chemiczne oddziaływanie środowiska $[9,13]$.

W prezentowanej pracy przedmiotem badań są struktura i właściwości tribologiczne czterech rodzajów powłok: $\mathrm{FeCuAl}-\mathrm{Al}_{2} \mathrm{O}_{3}$, WC-CoAl, Ni-Sn, TiC/Ti, nanoszonych techniką CGS. Celem badań było wytworzenie powłok, w których miedź, aluminium, kobalt, cyna oraz tytan stanowią ,miękką” osnowę, podczas gdy tlenki, węgliki i fazy międzymetaliczne: $\mathrm{Al}_{2} \mathrm{O}_{3}, \mathrm{WC}, \mathrm{Ni}_{3} \mathrm{Sn}, \mathrm{Ni}_{3} \mathrm{Sn}_{2}$, TiC, rozmieszczone równomiernie w osnowie spełniają rolę twardych, niemetalicznych cząstek umacniających.

Dobrym właściwościom mechanicznym stopów tytanu, w porównaniu z tradycyjnie stosowanymi materiałami inżynierskimi, nie towarzyszy odpowiednio wysoka odporność na ścieranie. Poprawę ich właściwości tribologicznych można uzyskać przez zastosowanie powłok, wykorzystując Ti jako miękką, plastycznie odkształcającą się osnowę, wiążącą twarde, umacniające powłokę cząstki TiC. Tym samym, przez odpowiedni dobór udziału objętościowego cząstek TiC i ich wielkości oraz równomierne rozmieszczenie w miękkiej osnowie Ti, można uzyskać powłoki o wysokiej twardości oraz odporności na ścieranie, oraz o właściwościach chemicznych podobnych do tytanu i jego stopów [10-12].

Właściwości tribologiczne nanostrukturalnych powłok $\mathrm{FeCuAl}-\mathrm{Al}_{2} \mathrm{O}_{3}, \mathrm{WC}-$ CoAl, Ni-Sn, TiC/Ti nanoszonych techniką CGS były porównywane z właściwościami materiałów powszechnie stosowanych w praktyce przemysłowej i zastosowaniach biomedycznych.

Szczegółowe wyniki badań dotyczące powłok $\mathrm{FeCuAl}-\mathrm{Al}_{2} \mathrm{O}_{3}$, Ni-Sn oraz TiC/Ti opublikowano we wcześniejszych pracach autorów $[9,12,15]$, natomiast większość wyników prezentowanych w niniejszej pracy dotyczy powłok WC-CoAl.

\section{Materiał i metodyka badań}

Proszki wytwarzano drogą mechanicznej syntezy poszczególnych składników dobranych w odpowiednich proporcjach, według procedury (Mechanomade ${ }^{\circledR}$ w MBN, Vascon, Włochy) przedstawionej szczegółowo w publikacji [16]. W ten sposób uzyskano proszek o wielkości cząstek 15-40 $\mu \mathrm{m}$, z twardymi cząstkami umacniającymi $\mathrm{Al}_{2} \mathrm{O}_{3}, \mathrm{WC}, \mathrm{Ni}_{3} \mathrm{Sn}, \mathrm{Ni}_{3} \mathrm{Sn}_{2}$ oraz $\mathrm{TiC}$, rozmieszczonymi w nanometrycznej osnowie $\mathrm{Al}, \mathrm{Cu}$, Ti lub Co-Al, o wielkości ziarna 20-50 nm. W kolej- 
nym etapie badań wytworzone proszki FeCuAl- $\mathrm{Al}_{2} \mathrm{O}_{3}$, WC-CoAl, Ni-Sn i TiC/Ti nanoszono techniką CGS (z wykorzystaniem systemu KINETICS 4000® firmy Impact Innovations $\mathrm{GmbH}$, Niemcy) na odpowiednio przygotowane podłoża $\mathrm{z}$ różnych materiałów (piaskowane płytki o wymiarach 50 x 20 x $5 \mathrm{~mm}$ ). Proszki $\mathrm{FeCuAl}-\mathrm{Al}_{2} \mathrm{O}_{3}$ oraz WC-CoAl nanoszono na podłoże ze stali konstrukcyjnej i stopu aluminium [9], TiC/Ti na podłoże ze stopu Ti6Al4V [12], natomiast Ni-Sn na podłoże ze stopu Inconel 718 [15]. Podczas nanoszenia proszków parametrami zmiennymi były: ciśnienie i temperatura gazu, odległość dyszy od podłoża, szybkość przemieszczania dyszy względem podłoża, stopień zachodzenia poszczególnych ściegów oraz liczba nałożonych kolejno warstw.

Mikrostrukturę i skład chemiczny proszków oraz powłok badano za pomocą mikroskopu skaningowego (SEM) FEI XL 30 FEG, wyposażonego w przystawkę EDS do mikroanalizy rentgenowskiej oraz za pomocą transmisyjnej mikroskopii elektronowej (TEM), wykorzystując mikroskopy JEOL JEM-200CX oraz Tecnai G2 F20. Cienkie folie do badań za pomocą TEM przygotowywano zarówno z cząstek proszków, jak i naniesionych powłok, stosując technikę zogniskowanej wiązki jonów Ga (FIB) w urządzeniu Dual Beam FEI oraz przez ścienianie jonowe $3 \mathrm{~mm}$ dysków wyciętych z powłok równolegle do ich powierzchni za pomocą ścieniarki PIPS firmy Gatan. Badania składu fazowego proszków i naniesionych powłok prowadzono za pomocą dyfrakcji promieni rentgenowskich (XRD), stosując dyfraktometr Empyrean Dy 1061, wykorzystując promieniowanie lampy $\mathrm{Cu} K \alpha(\lambda=0,154 \mathrm{~nm}) \mathrm{w}$ geometrii Bragg-Brentano. W celu określenia składu oraz stanów chemicznych pierwiastków na powierzchni proszków i powłok użyto rentgenowskiej spektroskopii fotoelektronów (XPS), stosując urządzenie firmy VSW Ltd. wyposażone w analizator energii elektronów pracujący w trybie stałej energii transmisji $22 \mathrm{eV}$. Użyto promieniowania $\operatorname{Mg} K \alpha(1253,6$ $\mathrm{eV}$ ). Kalibracji skali energii wiązania elektronów dokonywano, opierając się na położeniu linii przypadkowego węgla C $1 \mathrm{~s}$ na wartości $284,8 \mathrm{eV}$. Twardość i mikrotwardość naniesionych powłok mierzono w 10 różnych miejscach na przekroju powłok za pomocą twardościomierza Tukon 2500 firmy Wolpert-Wilson. Przed testami odporności na ścieranie próbki z powłokami były szlifowane za pomocą papierów ściernych i polerowane pastą diamentową do chropowatości powierzchni $\mathrm{Ra} \sim 0,1 \mu \mathrm{m}$. Odporność na ścieranie mierzono za pomocą tribometru opisanego w pracy [15] w temperaturze pokojowej. Próbką trącą był wypolerowany trzpień zakończony kuliście $(\mathrm{Ra} \sim 0,1 \mu \mathrm{m}, \mathrm{r}=5 \mathrm{~mm})$, wykonany ze stali 100Cr6 o twardości $800 \mathrm{HV}$, który w trakcie testu ścierania był obciążony siłą $2 \mathrm{~N}$. Przemieszczał się nad badaną próbką z częstotliwością $2 \mathrm{~Hz}$, na dystansie $200 \mu \mathrm{m}$ w czasie 10000 i 110000 cykli. Wszystkie testy ścierania były powtarzane trzykrotnie na każdej z próbek, a pomiar zużycia stanowi średnią wartość tych pomiarów. 


\section{Wyniki badań i ich dyskusja}

Na rysunku 1. pokazano obrazy SEM proszków $\mathrm{FeCuAl}-\mathrm{Al}_{2} \mathrm{O}_{3}$, WC-CoAl, Ni-Sn i TiC/Ti otrzymanych techniką mechanicznej syntezy na potrzeby realizowanych badań. Analiza obrazów wskazuje, że w wyniku mechanicznej syntezy tworzą się agregaty proszków o nieregularnych kształtach, które po przesianiu posiadały średnicę w granicach $15-40 \mu \mathrm{m}$, co pozwalało uzyskać zbliżoną energię kinetyczną cząstek podczas natryskiwania powłok, gwarantującą zwartą i jednorodną budowę natryskiwanego materiału. Szczegółowa analiza TEM cienkiej folii wyciętej z cząsteczki proszku WC-CoAl techniką FIB (rys. 2.) pokazuje, że drobne cząstki węglików WC są rozmieszczone równomiernie w nanostrukturalnej osnowie CoAl, co zostało potwierdzone charakterystyczną pierścieniową dyfrakcją elektronową (zamieszczoną w prawym górnym rogu na rys. 2a). Rysunki $2 \mathrm{~b}$ i c przedstawiają spektrogramy EDS zarejestrowane w odpowiednio oznaczonych obszarach na rys. $2 \mathrm{a}(\mathrm{z}$ węglika $\mathrm{WC}-\mathrm{b}$ oraz osnowy CoAl $-\mathrm{c})$.

Rys. 1. Obrazy SEM pokazujące typową morfologię proszków otrzymanych w wyniku mechanicznej syntezy: a) $\mathrm{FeCuAl}-\mathrm{Al}_{2} \mathrm{O}_{3}$, b) WC-CoAl, c) $\mathrm{Ni}-\mathrm{Sn}, \mathrm{d}) \mathrm{TiC} / \mathrm{Ti}$

Fig. 1. SEM images showing typical morphologies of powders produced by mechanical synthesis: a) $\mathrm{FeCuAl}-$ $\mathrm{Al}_{2} \mathrm{O}_{3}$, b) WC-CoAl, c) Ni-Sn, d) $\mathrm{TiC} / \mathrm{Ti}$

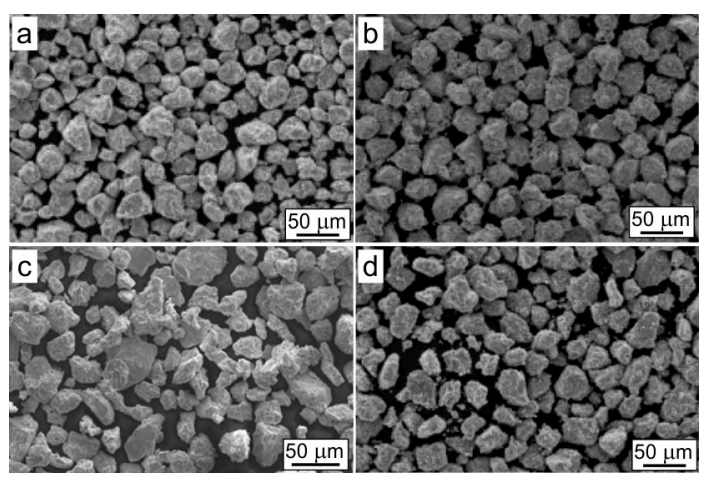

Wcześniejsze badania $[9,12,15,16]$ wykazały, że metoda mechanicznej syntezy proszków pozwala uzyskać cząsteczki proszków charakteryzujące się jednorodnym składem chemicznym oraz równomiernym rozmieszczeniem niemetalicznych faz umacniających (tlenków, węglików i faz międzymetalicznych) w nanostrukturalnej osnowie. Badania TEM (mikrofotografie i dyfraktogramy pierścieniowe) potwierdzają różną wielkość cząstek, WC, które są rozmieszczone w osnowie CoAl. Widoczne są cząstki WC o bardzo małych (rozmiar kilkunastu nanometrów) i większych (wielkości kilkaset nanometrów) rozmiarach.

W wyniku natryskiwania naddźwiękowego zimnym gazem wytworzono gęste powłoki cermetalowe $\mathrm{FeCuAl}-\mathrm{Al}_{2} \mathrm{O}_{3}, \mathrm{WC}-\mathrm{CoAl}$, Ni-Sn i TiC/Ti. Grubość powłok zmieniała się w zakresie od 45 do $500 \mu \mathrm{m}$. Typowe przekroje metalowo-ceramicznych powłok kompozytowych natryskiwanych zimnym gazem przedstawiono na rys. 3. Obserwacje SEM wykazały, że wszystkie powłoki otrzymane po optymalizacji parametrów procesu CGS są jednorodne, gęste, a między po- 
włoką a podłożem występuje dobrej jakości połączenie. Podczas procesu natryskiwania miękkie metale, pełniące funkcję osnowy, ulegają silnej deformacji, podczas gdy cząstki ceramiczne pozostają nieodkształcone, pełniąc funkcję cząstek umacniających powłokę kompozytową.

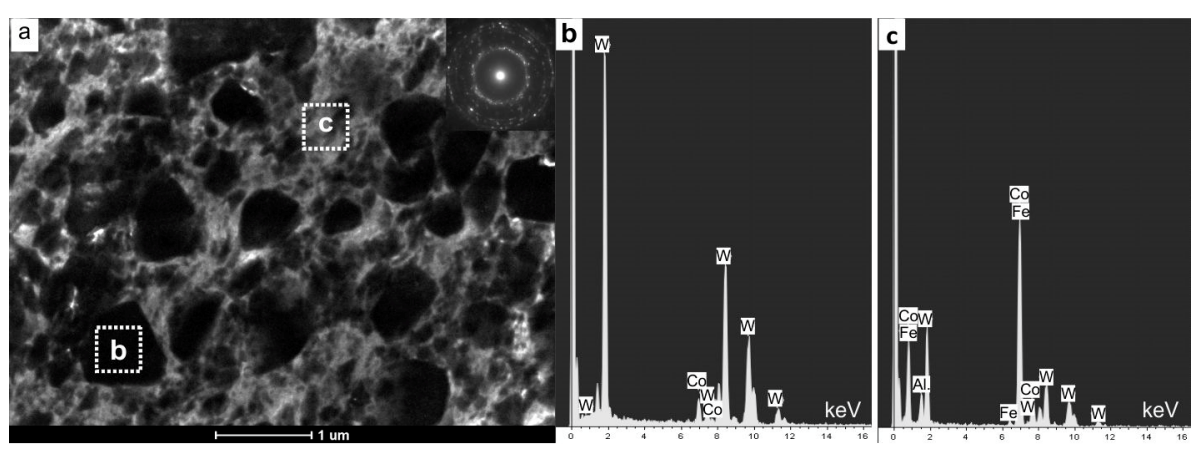

Rys. 2. Obraz TEM (a) pokazujący morfologię cząstki proszku WC-CoAl, dyfrakcja pierścieniowa wskazująca na nanostrukturalną budowę osnowy Co-Al, (b i c) spektrogramy EDS zarejestrowane w odpowiadających obszarach na mikrofotografii (a)

Fig. 2. TEM image (a) showing morphology of the WC-CoAl powder particle, ring diffraction pattern indicates nanostructured character of Co-Al matrix, (b and c) EDS spectrograms recorded in the marked areas on micrograph (a)

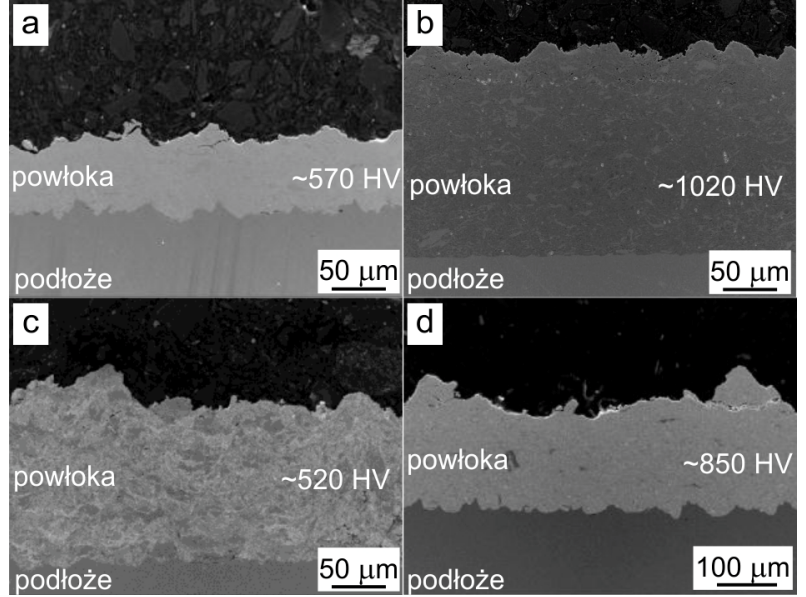

Rys. 3. Obrazy SEM przekrojów powłok otrzymanych techniką CGS: a) $\mathrm{FeCuAl}-\mathrm{Al}_{2} \mathrm{O}_{3}$, b) WCCoAl, c) Ni-Sn, d) TiC/Ti. Podane wartości twardości HV są średnimi 5 pomiarów

Fig. 3. SEM images show crosssections of CGS coatings: a) Fe$\mathrm{CuAl}-\mathrm{Al}_{2} \mathrm{O}_{3}$, b) WC-CoAl, c) Ni$\mathrm{Sn}$, d) $\mathrm{TiC} / \mathrm{Ti}$. Presented values of hardness $\mathrm{HV}$ are averages of 5 measurements

Wzrost twardości powłoki jest wynikiem efektu utwardzania odkształceniowego, wynika również z obecności bardzo twardych, superdrobnych cząstek ceramicznych. W obszarze połączenia powłoki i podłoża widoczny jest duży stopień deformacji podłoża przez padające cząstki proszków tworzących powłokę, co znacząco poprawia połączenie pomiędzy powłoką a podłożem. Powłoki 
WC-CoAl osadzane metodą CGS na podłożu ze stopu aluminium mają zmienną (zależną od parametrów procesu osadzania) grubość w przedziale od 45 do $180 \mu \mathrm{m}$, przy czym grubość ta jest stosunkowo jednorodna dla poszczególnych powłok. Obserwacje SEM przekrojów powłok wykazują, że posiadają one dobrą przyczepność do podłoża (rys. 3b).

Badania TEM (rys. 4.) potwierdzają strukturę wykonaną z małych cząstek (wielkości nanometrycznych) WC osadzonych w osnowie CoAl. Taka mikrostruktura jest korzystna, ponieważ małe i twarde cząstki WC zapewniają wysoką twardość i odporność na zużycie powłok, a stosunkowo miękki materiał osnowy CoAl zapewnia wysoką udarność. Ponadto mocno rozdrobnione i równomiernie rozmieszczone w osnowie cząstki węglika korzystnie wpływają na właściwości mechaniczne.

Badania TEM powłok WC-CoAl wskazują, że w ich mikrostrukturze obserwuje się zarówno większe (o średnicy 150-200 nm), jak i bardzo drobne cząstki WC o średnicy kilkunastu nm (rys. 4.). Szczegółowe obserwacje TEM wskazują ponadto na bardzo mocne zdefektowanie mikrostruktury powstałych powłok, co potwierdza silne odkształcenie materiału i powstanie naprężeń ściskających.

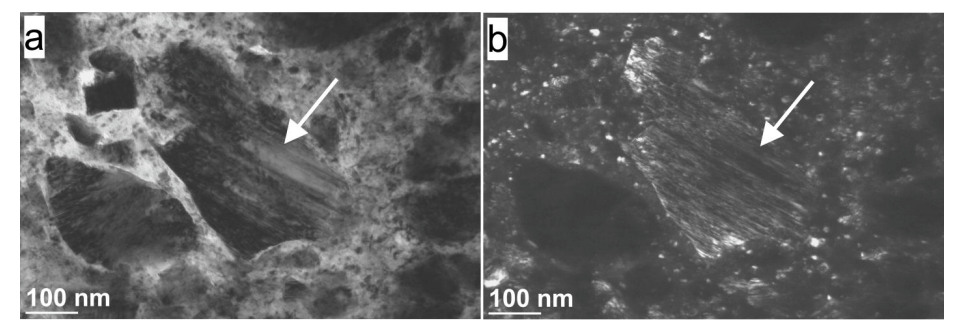

Rys. 4. Obraz TEM mikrostruktury powłoki WC-CoAl natryskiwanej metodą CGS z widocznymi większymi, silnie odkształconymi oraz bardzo drobnymi węglikami WC: a) obraz w jasnym polu, b) obraz w ciemnym polu

Fig. 4. TEM images of WC-CoAl coating deposited by the CGS method, showing larger, mostly deformed and very fine WC carbides: a) brightfield image, $b$ ) dark-field image

Badania proszków oraz powłok za pomocą rentgenowskiej analizy fazowej (rys. 5.) wykazują, że w ich składzie można zidentyfikować węglik wolframu WC oraz materiał osnowy CoAl. Analiza składu fazowego przeprowadzona metodą XRD (rys. 5b) pokazuje, że w składzie powłok można wyróżnić, podobnie jak w przypadku proszków przygotowanych w procesie mechanicznej syntezy (rys. 5a), które są materiałem wyjściowym do natryskiwania, jedynie cząstki wzmacniające WC oraz osnowę CoAl. Średnia wielkość krystalitów obliczona metodą Williamsona-Halla dla fazy WC zawiera się pomiędzy 22 a $95 \mathrm{~nm}$, w zależności od parametrów osadzania. Badania dyfrakcji rentgenowskiej powłok WC-CoAl 
wskazują, że udział objętościowy poszczególnych faz można oszacować: dla fazy WC około $78 \%$ i dla fazy CoAl około $22 \%$.

Rysunek 6. przedstawia wyniki analizy XPS proszku oraz powłok WC-CoAl wraz z ich interpretacją. Metoda XPS pozwala na analizę wierzchniej warstwy materiału o grubości zaledwie kilku nanometrów. Jest to zatem metoda wybitnie powierzchniowa. Pokazano tylko analizy pierwiastków metalicznych, ale analizowano także linię węgla oraz tlenu. Aluminium i kobalt na powierzchni proszków występują tylko w jednym stanie chemicznym, jako tlenki $\mathrm{Al}_{2} \mathrm{O}_{3}$ oraz $\mathrm{CoO}$.
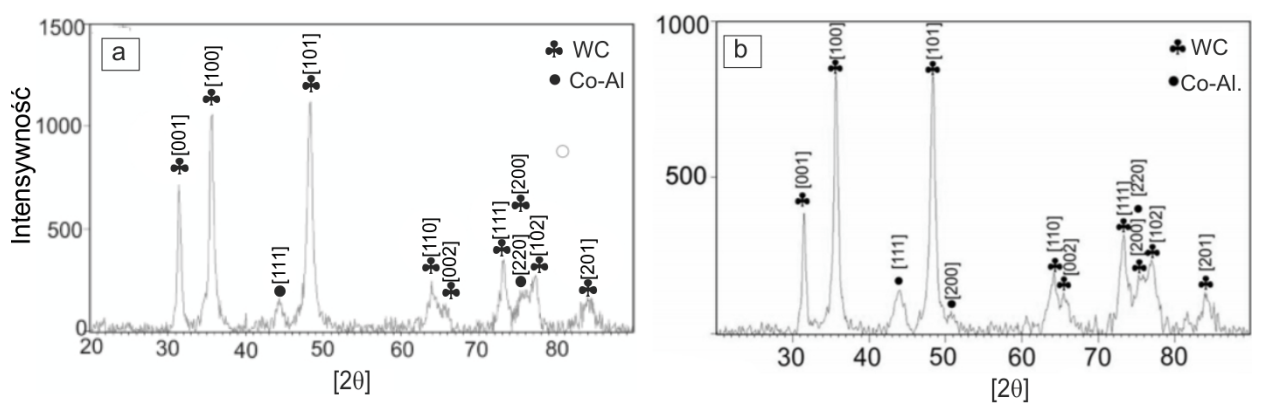

Rys. 5. Wyniki rentgenowskiej analizy fazowej proszku (a) otrzymanego w procesie mechanicznej syntezy i powłoki WC-CoAl (b) natryskiwanej metodą CGS

Fig. 5. X-ray diffraction pattern of the powder (a) obtained in the process of mechanical synthesis and WC-CoAl (b) coating deposited by the CGS method

Wolfram występuje w nieco bardziej złożonym stanie chemicznym, gdyż widoczny jest wolfram metaliczny, w postaci węglika WC oraz w postaci niestechiometrycznego tlenku $\mathrm{WO}_{3-\mathrm{x}}$. W przypadku powłoki stwierdzono identyczne stany chemiczne Al, W i Co, ale nieco zmienione są ich stosunki ilościowe. Powierzchnia powłoki jest bogatsza w wolfram. Aluminium i kobalt na powierzchni są całkowicie utlenione, podobnie jak w proszku, natomiast znacznie mniejsza jest ilość wolframu zawartego $\mathrm{w}$ tlenku, a większa $\mathrm{w}$ postaci metalicznej $\mathrm{i} w$ węgliku w porównaniu z proszkiem. Ponadto stosunek ilości węglika do wolframu metalicznego wzrósł w porównaniu z proszkiem.

Analiza XPS wykazała, że proszki otrzymane w wyniku wysokoenergetycznego mielenia w atmosferze ochronnej stają się aktywne chemicznie i ich powierzchnia na skutek późniejszego kontaktu z powietrzem utleniła się. Udział tlenków w warstwie wierzchniej powłok zmniejsza się w porównaniu z proszkami.

Skład chemiczny i fazowy warstwy wierzchniej wykazuje zatem pewne odstępstwa od składu wnętrza dużych aglomeratów nanoziaren, których skład chemiczny i fazowy określiły analizy EDS oraz XRD. 

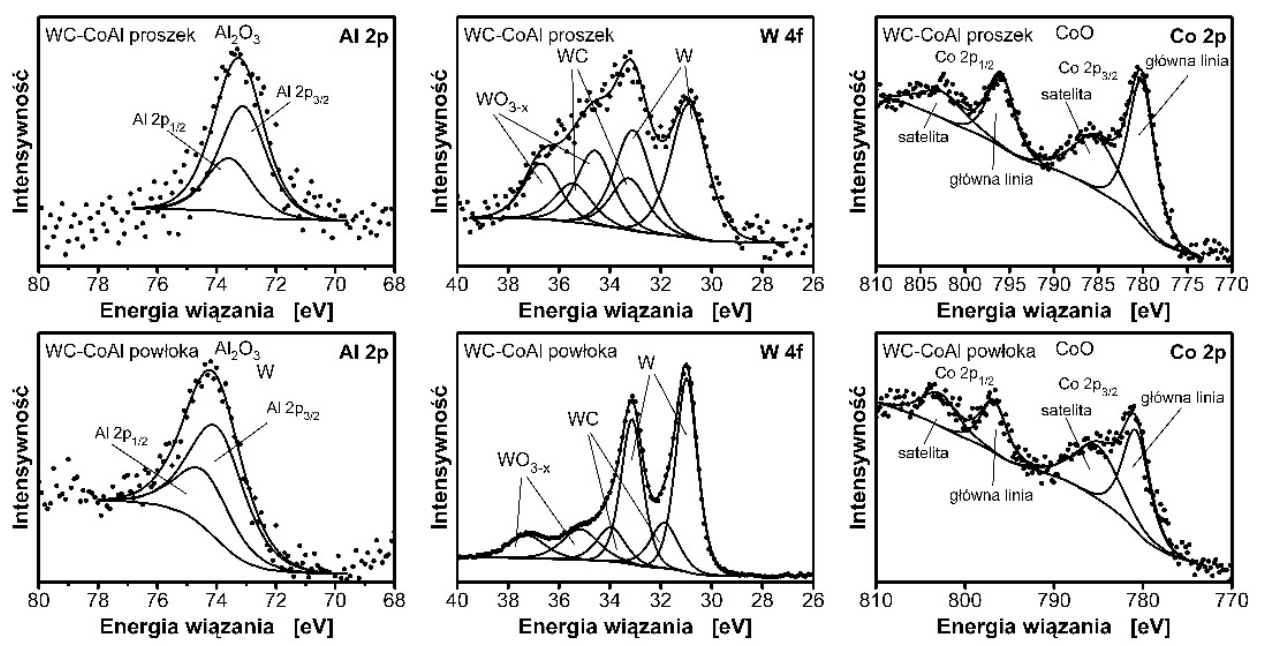

Rys. 6. Analiza XPS proszku WC-CoAl oraz naniesionej powłoki

Fig. 6. XPS analysis of the WC-CoAl powder and the deposited coating

Jak wcześniej wspomniano, natryskiwane powłoki mogą być stosowane w różnych układach tribologicznych, jako powłoki o dużej odporności na ścieranie. W ramach badań wykonano pomiary współczynnika tarcia natryskiwanych powłok i porównano ze współczynnikami tarcia dla innych materiałów powszechnie stosowanych jako powłoki zabezpieczające przed zużyciem ściernym (rys. 7.). Wyniki pomiarów wskazują, że zarówno powłoka Ti/TiC, jak i powłoka FeCuAl$\mathrm{Al}_{2} \mathrm{O}_{3}$ posiadają niższy współczynnik tarcia (w skojarzeniu w węźle tarcia z przeciwpróbką korundową) niż inne materiały odniesienia, np. stal proszkowa, stellity czy stale stopowe. Wyniki pomiarów zaprezentowane na diagramie (rys. 7a) wskazują, że powłoki te charakteryzują się również znacząco mniejszym zużyciem ściernym (wyrażonym przez głębokość wytarcia) niż inne badane materiały odniesienia: stal proszkowa, stellity czy stale stopowe. Wyniki pomiarów zaprezentowane na diagramie (rys. 7a) wskazują, że powłoki te charakteryzują się również znacząco mniejszym zużyciem ściernym (wyrażonym przez głębokość wytarcia) niż inne badane materiały odniesienia. Szczegółowe wyniki badań przedstawiono we wcześniejszych publikacjach autorów $[9,14]$. Testom odporności na zużycie ścierne poddano również powłoki cermetalowe WC-CoAl natryskiwane zimnym gazem (rys. 7b). Wyniki pomiarów wykazały, że posiadają one doskonałą odporność na zużycie.

Wykonano również testy odporności na ścieranie dla powłok WC-CoAl natryskiwanych termicznie powszechnie stosowaną metodą HVOF oraz powłok natryskiwanych metodą CGS. Wyniki pomiarów wykazują, że nanokrystaliczne powłoki nanoszone metodą CGS posiadają znacznie lepszą odporność na ścieranie niż powłoki natryskiwane metodą HVOF. 
W zestawieniu (rys. 7b) podano wyniki dla serii próbek natryskiwanych przy tych samych parametrach procesów, a linią przerywaną zaznaczono wartości średnie zużycia dla każdego z procesów natryskiwania.
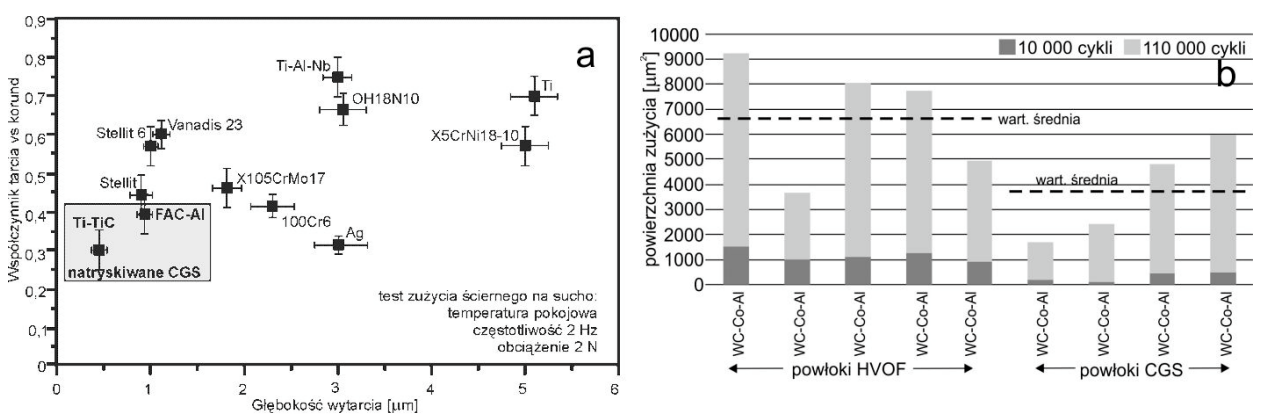

Rys. 7. Wyniki testów odporności na ścieranie powłok (FAC-Al - $\mathrm{FeCuAl}-\mathrm{Al}_{2} \mathrm{O}_{3}$ ) natryskiwanych metodą CGS w porównaniu z innymi materiałami (a) oraz testów odporności na ścieranie powłok WC-CoAl natryskiwanych metodą CGS $\mathrm{w}$ porównaniu z powłokami natryskiwanymi metodą HVOF (b)

Fig. 7. The results of the wear resistance tests of CGS (FAC-Al $-\mathrm{FeCuAl}-\mathrm{Al}_{2} \mathrm{O}_{3}$ ) coatings in comparison with other materials (a) and wear resistance tests of $\mathrm{WC}-\mathrm{CoAl}$ coatings sprayed with the CGS method in comparison with HVOF-deposited coatings (b)

\section{Podsumowanie}

Proszki z różnych materiałów: $\mathrm{FeCuAl}-\mathrm{Al}_{2} \mathrm{O}_{3}$, WC-CoAl, Ni-Sn, TiC/Ti, jako materiały wyjściowe do natryskiwania powłok metodą CGS wytworzono techniką mechanicznej syntezy. Tak przygotowane proszki posiadały wielkość ziarna w zakresie od 15 do $40 \mu \mathrm{m}$ oraz nanokrystaliczną strukturę, np. dla proszku WC-CoAl wielkość krystalitów wynosiła od 10 do $20 \mathrm{~nm}$. Powłoki nałożone na podłoża metodą CGS posiadały dobrą adhezję do materiału podłoża, które w procesie natryskiwania ulegało silnej deformacji. Powłoki posiadają wysoką gęstość, nie obserwowano w nich istotnej porowatości czy delaminacji. Powłoki posiadają strukturę warstwową, powstałą na skutek uderzeń o ogromnej energii kolejnych cząstek proszków, które ulegają silnej deformacji i wzajemnie łączą się adhezyjnie i mechanicznie. Wytworzone powłoki posiadają budowę metalowo-ceramicznych kompozytów, gdzie fazą umacniającą są $\mathrm{Al}_{2} \mathrm{O}_{3}, \mathrm{WC}, \mathrm{Ni}_{3} \mathrm{Sn}, \mathrm{Ni}_{3} \mathrm{Sn}_{2}$ oraz TiC, natomiast osnowę stanowią metale: $\mathrm{Al}, \mathrm{Cu}$, Ti czy stop CoAl. Wytworzone powłoki posiadają korzystne właściwości tribologiczne, takie jak niski współczynnik tarcia oraz dobra odporność na ścieranie w porównaniu z innymi materiałami stosowanymi jako odporne na ścieranie powłoki. Ponadto testy odporności na ścieranie wykazują, że metaliczno-ceramiczne powłoki kompozytowe WC-CoAl, natryskiwane metodą CGS cechują się prawie dwukrotnie lepszą odpornością na 
ścieranie niż powłoki z tego samego materiału, ale natryskiwane powszechnie stosowaną metodą HVOF.

\section{Podziękowania}

Badania sfinansowano ze środków statutowych Wydziału Inżynierii Metali i Informatyki Przemysłowej AGH, umowa nr: 11.11.110.295. Częściowo wykorzystano do badań materiały wytworzone $w$ ramach projektu UE Supersonic, nr FP7-NMP-2008 LARGE-2 CP-IP 228814-2.

\section{Literatura}

[1] Rickerby D.S., Matthews A.: Advanced Surface Coatings: a Handbook of Surface Engineering, Chapman and Hall, New York 1991.

[2] Burakowski T., Wierzchoń T.: Surface engineering of metals: principles, equipment, technologies, CRC Press, 1999.

[3] Davis J.R.: Editor, Surface Engineering for Corrosion and Wear Resistance, ASM International, 2001.

[4] Jodoin B., Ajdelsztajn L., Sansoucy E., Zúñiga A., Richer P., Lavernial E.J.: Effect of particle size, morphology, and hardness on cold gas dynamic sprayed aluminum alloy coatings, Surface Coatings Technol., 201 (2006) 3422-3429.

[5] Fauchais P., Vardelle A., Dussoubs B.: Quo vadis thermal spraying?, J. Thermal Spray Technol., 10 (2001) 44-66.

[6] Senderowski C.: Żelazowo-aluminiowe intermetaliczne systemy powłokowe uzyskiwane $\mathrm{z}$ naddźwiękowego strumienia metalizacyjnego, Wydawnictwo WAT, Warszawa 2015.

[7] Assadi H., Gärtner F., Stoltenhhoff T., Kreye H.: Acta Materialia, 51 (2003) 379$-4394$.

[8] Cadney S., Brochu M., Richer P., Jodoin B.: Cold gas dynamic spraying as a method for freeforming and joining materials, Surface Coatings Technol., 202 (2008) 2801-2806 .

[9] Georgiou E.P., Achanta S., Dosta S., Fernandez J., Matteazzi P., Kusiński J., Piticescu R.R., Celis J.-P.: Structural and tribological properties of supersonic sprayed Fe$\mathrm{Cu}-\mathrm{Al}-\mathrm{Al}_{2} \mathrm{O}_{3}$ nanostructured cermets, Applied Surface Scie., 275 (2013) 142-147.

[10] Leyens C., Peters M., eds.: Titanium and titanium alloys, Wiley-VCh., Weinheim 2003.

[11] Alman D.E., Hawk J.A.: The abrasive wear of sintered titanium matrix-ceramic particle reinforced composites, Wear, 225-229 (1999) 629-639.

[12] Kąc S., Szwachta G., Kusiński J., Matteazzi P., Colella A., Dosta S., Fernandez J., Garcia-Forgas J.: Structural and chemical investigation into Ti/TiC coatings deposited with Cold Gas Spraying (CGS), Mater. Eng., 35 (2014) 150-153.

[13] Guilemany J.M., Dosta S., Nin J., Miguel J.R.: Study of the properties of WC-Co nanostructured coatings sprayed by high-velocity oxyfuel, J. Thermal Spray Technol., 14 (2005) 405-413. 
[14] Basak A.K., Celis J.-P., Vardavoulias M., Matteazzi P.: Effect of nanostructuring and $\mathrm{Al}$ alloying on friction and wear behaviour of thermal sprayed WC-Co coatings, Surface Coatings Technol., 206 (2012) 3508-3516.

[15] Kusiński J., Kąc S., Kowalski K., Dubiel B., Dymek S., Czyrska-Filemonowicz A., Dosta S., Celis J.-P., Georgiou E., Matteazzi P.: Microstructural characterization of nanostructured supersonic sprayed Ni-Sn coatings after wear tests at elevated temperature, Int. J. Mater. Research, 106 (2015) 750-757.

[16] Matteazzi P., Alcala M.: Mechanomaking of $\mathrm{Fe} / \mathrm{Al}_{2} \mathrm{O}_{3}$ and $\mathrm{FeCr} / \mathrm{Al}_{2} \mathrm{O}_{3}$ nanocomposites powders fabrication, Mater. Sci. Eng. A, 230 (1997) 161-170.

\title{
WEAR RESISTANT COATINGS DEPOSITED BY COLD GAS SPRAYINMG
}

\begin{abstract}
A bstract
The basic scientific and technological aim of the research was the generation of nano-structured $\mathrm{FeCuAl}-\mathrm{Al}_{2} \mathrm{O}_{3}, \mathrm{WC}-\mathrm{CoAl}, \mathrm{Ni}-\mathrm{Sn}$, TiC/Ti coatings having thicknesses of about 100-500 $\mu \mathrm{m}$. High energy ball milling synthesis allowed the production of powders characterized by fine and homogeneous chemical distribution of elements, and an "ultrafine" (nanometer scale) crystalline structure. A new powerful deposition technology (Cold Gas Spray - CGS) was used to transfer the nanophased powder onto the substrate in the form of a dense coating with very little or no change of crystal structure and properties. The microstructure and composition of all prepared nano-powders and deposited coatings were investigated using light microscopy, TEM, STEM, SEM/EDS, XPS and XRD techniques. Hardness, and measurement of the coefficient of friction and wear resistance were carried out on the deposited coatings. It was found that the microstructure of the powder is maintained in the deposited coating. The nanophased structure, with an appropriate balance of hard and soft phases, allows the CGS coatings to exhibit better tribological properties than that of the examined benchmark materials.
\end{abstract}

Keywords: high energy ball milling, cermet coatings, microstructure, hardness, tribological tests

DOI: $10.7862 / \mathrm{rm} .2018 .14$

Przestano do redakcji: 27.04 .2018

Przyjęto do druku: 22.05.2018 